\title{
Co-designing Research Methods Lesson Plans in the Interactive Research Methods Lab
}

\author{
Codiseñando Unidades Didácticas sobre Métodos de Investigación en el \\ Interactive Research Methods Lab
}

Iván.M Jorrín-Abellán; ijorrina@kennesaw.edu

Anete Vasquez; avasque8@kennesaw.edu

Rachel E. Gaines; rgaines7@kennesaw.edu

Kennesaw State University (USA)

\begin{abstract}
In this article we present a series of co-design sessions conducted throughout the 2019-2020 academic year, of which the aim was to plan and implement lessons on research methods for undergraduate and graduate students in the Interactive Research Methods Lab (IRML). The IRML is a brand new resource in the Bagwell College of Education (Kennesaw State University) that provides students with personalized instruction and practical experience in generating research designs, conceptual frameworks, and reviews of literature using Augmented Reality (AR) interactive contents. We followed the seven characteristic features of codesign as outlined by Roschelle et al. (2006) and structured sessions for co-design in accordance with Cober et al. (2015) and Barberá et al.'s (2017) proposed stages: a) Exploration, b) Envisioning, c) Operationalization, and d) Assessment and Reflection.

Successful implementation of the co-designed lessons and their integration with the IRML as a technological learning resource highlight the affordances of using a co-design approach to confront the inherent challenges in designing authentic and meaningful learning experiences when teaching research methods.
\end{abstract}

Keywords: Co-design, research methods, Interactive Research Methods Lab

\section{Resumen}

En este artículo presentamos un conjunto de sesiones de codiseño realizadas en otoño de 2019 y primavera de 2020, con el objetivo de diseñar e implementar unidades didácticas sobre métodos de investigación para estudiantes de grado y de doctorado en el Interactive Research Methods Lab (IRML). El IRML es un nuevo recurso con el que cuenta el Bagwell College of Education (Kennesaw State University), que brinda a los estudiantes una experiencia personalizada y práctica en la generación de diseños de investigación, marcos conceptuales, y revisiones de literatura utilizando para ello contenidos interactivos de Realidad Aumentada (RA). El enfoque seguido en las sesiones de codiseño se basó en las recomendaciones de Roschelle, et al. (2006), y se estructuró de acuerdo a las cuatro fases propuestas por (Cober et al., 2015) y (Barberá et al., 2017): a) Exploración; b) Previsión; c) Operacionalización, y: d) Fase de evaluación y reflexión.

La implementación exitosa de las unidades didácticas sobre métodos de investigación que emplean el IRML como un recurso de aprendizaje tecnológico, constituye una evidencia clara de las posibilidades de usar un enfoque de codiseño para abordar las dificultades intrínsecas que entraña la enseñanza de métodos de investigación.

Palabras clave: Codiseño, métodos de investigación, Interactive Research Methods Lab 


\section{INTRODUCTION.}

The day-to-day work of P-12 teachers has become increasingly challenging due to the constant reforms, mandated curriculum overhaul, and burden of standardized assessment (Mulholland et al., 2016). Rich subject area and pedagogical knowledge are necessary for effective teachers, but this is no longer sufficient. In response to national, regional, and local education reforms, teachers must become lifelong, multifaceted learners and reflective professionals able to transform their own practice based on systematic analyses (Scheeler et al., 2016). More than ever teachers need to become vanguard agents in providing rigorous evidence on which to ground education practice. This will only be attainable if we offer teachers improved methods, tools, and procedures to enable them to thoroughly analyze their daily practices.

With this in mind, in fall 2019 we launched the Interactive Research Methods Lab (IRML) in Kennesaw State University's Bagwell College of Education. This innovative space challenges mainstream approaches to the teaching and learning of research methods in education. Through the use of ad hoc multimedia and interactive AR contents, the IRML allows students to collaboratively generate well-informed qualitative, quantitative, and mixed-methods research designs, literature reviews, and conceptual frameworks. The current version of the IRML, whether accessed virtually or face-to-face, provides multimodal and hands-on learning experiences aligned with the principles of social constructivism (Vygotsky, 1978), progressive education (Dewey, 1916), and the Open Science movement (European Commission, 2016).

In this paper we present and discuss a series of co-design sessions that took place throughout the 2019-2020 academic year in which members of the IRML team collaborated with faculty (instructors) interested in embedding the IRML as a resource into their courses. These co-design sessions, which honored the seven characteristic features of co-design posed by Roschelle et al. (2006), were instrumental in developing individualized lesson plans that faculty subsequently implemented with students in the IRML. In the context of these sessions, co-design was understood as a creative process developed collaboratively by teachers, students, and researchers to design inquiry-based, technology-enhanced, networked-learning scenarios (García et al., 2014).

Similar to previous co-design literature (Könings et al., 2011; Sanders \& Stappers, 2001), the focal objects of our co-design work were course curricula. Specifically, we collaborated with faculty to co-design lessons that supported students' understanding of and ability to create effective research designs, literature reviews, or conceptual frameworks. Faculty involved in the co-design process adopted an apprentice role, learning to leverage the IRML in teaching research design/ methods as they collaborated with the IRML team, which was composed of six experts in educational research methods. 
The use of a co-design in developing and implementing authentic, meaningful learning experiences in research methods courses may ameliorate the fundamentally intimidating nature of teaching and learning research methods (Cooper et al., 2012; Lesko et al., 2008). Furthermore, increased use of co-design in research methods courses may highlight the paucity of attention given in the literature to the teaching and learning of research methods (Günter, 2008).

\section{THE INTERACTIVE RESEARCH METHODS LAB.}

The overall mission of the IRML is to improve the education of students and faculty who are learning and teaching research designs in social sciences and education by curating/creating practical, informative resources and delivering them via innovative methods. The lab also aims at drawing meaningful connections between educational research methods/design and the real world, with particular focus on schools, school districts, and the communities our students and faculty serve. The long-term goal of the lab is to promote data-driven decision-making (DDDM), or the "systematic collection, analysis, examination, and interpretation of data to inform practice and policy in educational settings" (Mandinach, 2012, p. 71), non-profit organizations, and public institutions. To achieve this goal, we must support social agents in learning how to implement research-based practices.

Although DDDM is difficult to study due to its multifaceted, context-sensitive nature, there is evidence to suggest that it "can be a powerful tool for revealing needed changes, and for questioning long-held assumptions" (Gullo, 2013, p. 415). Many reviews of research on the impact of DDDM have reported mixed results (e.g., Marsh, 2012); however, Piety's (2019) review of more than 570 articles on DDDM noted that "impact studies [of DDDM] typically focused on specific areas such as classrooms, professional learning communities, or district meetings" (p. 407). In contrast, examining the impact of data use across contexts (e.g., districts, states, grade levels) may prove a more promising approach to understanding the impact of DDDM. Furthermore, DDDM initiatives such as professional learning communities (PLC) and studentfocused instructional coaching can promote a culture of inquiry among teachers and social agents.

\subsection{Components of the Interactive Research Methods Lab}

The IRML offers undergraduate and graduate students and novice researchers interested in generating methodologically-sound research designs an across-spaces learning experience (Muñoz-Cristóbal et al., 2015), meaning that users are able to interact with and in different faceto-face, virtual, and augmented modalities. The layout and contents of the lab are aligned with the Open Science movement (European Commission, 2016) and based on the principles of Dewey's (1916) Learning by Doing theory and progressive education (i.e., hands-on projects, expeditionary learning, focused thematic units, problem solving and critical thinking, 
collaborative learning, personalized learning, and the integration of community service and service learning projects).

The IRML offers an interactive physical space located in the Bagwell College of Education at Kennesaw State University, and a virtual interactive space for distance students and faculty interested in experiencing a collaborative and structured approach to thinking through the different stages involved in generating research designs.

As represented in figure 1-A, the walls of the physical lab provide an interactive itinerary organized around the nine steps for developing research designs as proposed by the Hopscotch model (Jorrín-Abellán, 2016, 2019). Each step is placed on a customized decal over a dry-erase surface on which users are able to write down ideas and make decisions based on information provided in the AR contents (see lower side of figure 1-A). The AR contents were created by our team using Metaverse Studio (n.d.), a tool for the creation of AR learning experiences that uses a block programming interface. Users of the lab, with as-needed assistance from the research methodologists on our team (two quantitative methodologists, one qualitative, and a graduate librarian), are able to visualize and interact with the AR contents by pointing their own devices (i.e., cell phones, iPads) at the AR markers embedded in the decals on the walls.
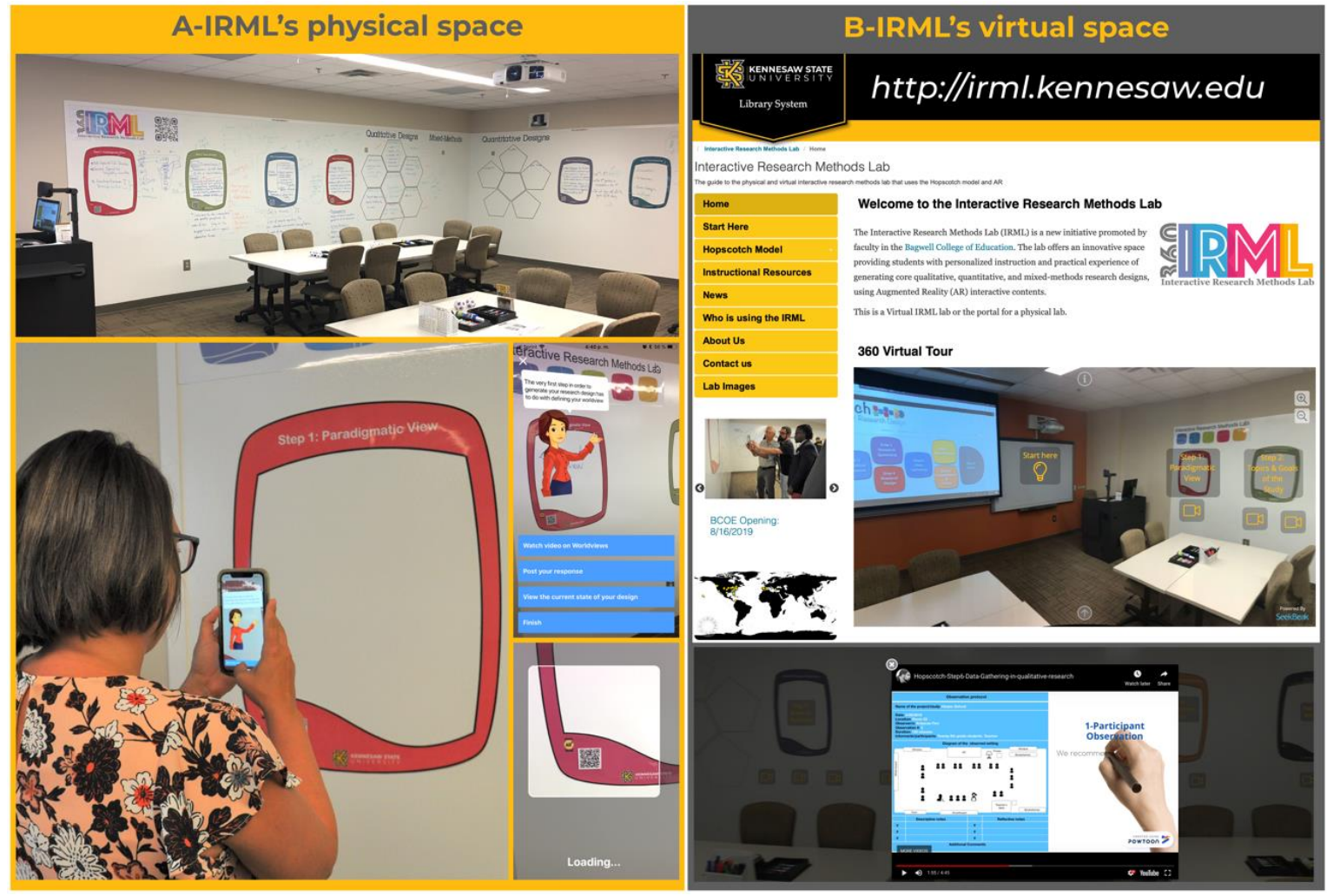

Figure 1. IRML's Physical \& Virtual Spaces 
For each of the nine steps, the AR content describes the purpose of the step, directs users to watch a brief overview video about the topic, provides scaffolded resources, and asks users to respond to a culminating question (e.g., "Are you ready to define your research topic?"). The answers, provided in both textual and multimedia fashion, are collected on a virtual "wall" by the Metaverse system. User responses are then projected on the main screen in the IRML, thereby promoting active discussion and reflective thinking about the methodological choices being made.

A second component of the IRML is its virtual interactive space (see figure 1-B and figure 2; see: http://irml.kennesaw.edu). One key element of the virtual space is the $360^{\circ}$ virtual tour that replicates the experience students have in the physical space. As shown in figure 2, online users can access the virtual tour and use their phone or tablet to scan the AR codes that are associated with the points of interest included for each step of the process. Students may also use a virtual reality headset if they prefer an immersive experience while interacting with the AR contents.

It is noteworthy as well that LibGuides (a product of SpringShare), the system used to create the virtual lab space, allows the IRML to be integrated seamlessly into Desire2Learn (D2L) Brightspace, the learning management system used by many K-12 school districts, colleges, and universities. As a result, for faculty at our institution who teach research methods courses using $\mathrm{D} 2 \mathrm{~L}$, the IRML becomes an embeddable resource, allowing online students to benefit from the IRML remotely.
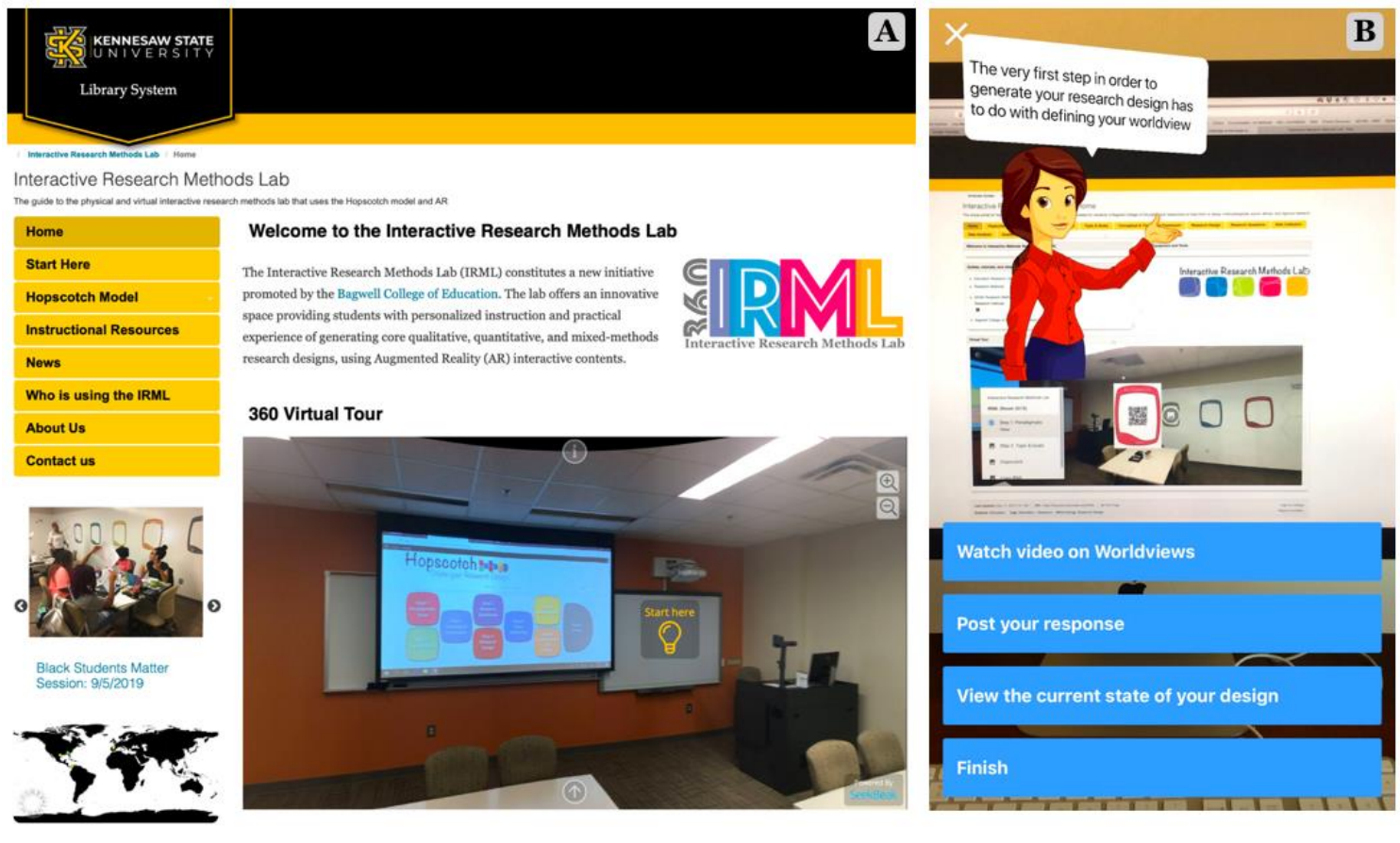

Figure 2. Configuration of the IRML's Virtual Space (see: https://irml.kennesaw.edu) 


\section{STRUCTURE OF THE CO-DESIGN SESSIONS.}

From August 2019 to February 2020, five lesson plans were co-designed by the IRML team in collaboration with faculty (instructors) interested in embedding the IRML as a resource into their regular courses or extra-curricular activities. Two of the sessions were devoted to undergraduate students, three to graduate ones. Four of the five lesson plans were to be used in undergraduate (1) or graduate courses (3), while the fifth lesson plan was co-designed with the faculty advisors of Black Teachers Matter, an undergraduate student organization.

The co-design of each lesson plan involved at least one member of the IRML and one faculty member who would be teaching the lesson. The complete co-design process for each lesson plan took approximately two weeks, including both face-to-face and virtual collaborative work. The generated lesson plans were intended for audiences in a variety of graduate (i.e., Advanced Qualitative Research Methods ${ }^{1}$, Comparative Education ${ }^{2}$, Conceptual Frameworks \& Research Design $^{3}$ ) and undergraduate courses (i.e., Senior Capstone in Human Services ${ }^{4}$ ) and student organizations (i.e., Black Teachers Matter; BTM) ${ }^{5}$.

In order to describe the co-design features of these five sessions, we used the nine characteristics of effective co-design proposed by Barberá et al. (2014) (see table 1), which expand upon the initial seven developed by Roschelle et al. (2006, p.607). The ultimate goal of the co-design sessions was to collaborate in developing lesson plans that, when implemented, would catalyze authentic active learning experience for students in the IRML. The generated lesson plans included use of both $A R$ contents and multimedia resources to help students generate tangible products, such as original research designs, literature review synthesis matrices, visual representations of research designs, and visual representations of supporting conceptual frameworks. Additional information about these products is provided in table 1 .

Table 1. Characteristics of the Five Co-design Sessions

\begin{tabular}{|l|l|l|l|l|l|}
\hline Characteristics & \multicolumn{1}{|c|}{$\begin{array}{c}\text { Black Teachers } \\
\text { Matter (BTM) }\end{array}$} & $\begin{array}{c}\text { Advanced } \\
\text { Qualitative } \\
\text { Research Methods } \\
\text { (AQRM) }\end{array}$ & $\begin{array}{l}\text { Comparative } \\
\text { Education (CE) }\end{array}$ & $\begin{array}{l}\text { Conceptual } \\
\text { Frameworks \& } \\
\text { Research Design } \\
\text { (CFRD) }\end{array}$ & $\begin{array}{l}\text { Senior Capstone } \\
\text { in Human Services } \\
\text { (SCHS) }\end{array}$ \\
\hline $\begin{array}{l}\text { Concrete and } \\
\text { tangible innovation } \\
\text { challenge. }\end{array}$ & $\begin{array}{l}\text { The goal of the co- } \\
\text { designed session was } \\
\text { to develop and } \\
\text { implement a lesson } \\
\text { plan for } \\
\text { undergraduate }\end{array}$ & $\begin{array}{l}\text { The goal of the co- } \\
\text { designed session was } \\
\text { to develop and } \\
\text { implement a lesson } \\
\text { plan for graduate } \\
\text { students to generate }\end{array}$ & $\begin{array}{l}\text { The goal of the co- } \\
\text { designed session } \\
\text { was to develop and } \\
\text { implement a lesson } \\
\text { plan for graduate } \\
\text { students to }\end{array}$ & $\begin{array}{l}\text { The goal of the co- } \\
\text { designed session was } \\
\text { to develop and } \\
\text { implement a lesson } \\
\text { plan for graduate } \\
\text { students to generate }\end{array}$ & $\begin{array}{l}\text { The goal of the co- } \\
\text { designed session } \\
\text { was to develop and } \\
\text { implement a lesson } \\
\text { plan for } \\
\text { undergraduate }\end{array}$ \\
\hline
\end{tabular}

${ }^{1}$ See: https://libguides.kennesaw.edu/ld.php?content id=50524256

${ }^{2}$ See: $\underline{\text { https://libguides.kennesaw.edu/ld.php?content_id }=50633842}$

${ }^{3}$ See: https://libguides.kennesaw.edu/ld.php?content_id=50735461

${ }^{4}$ See: https://libguides. kennesaw.edu/ld.php?content id $=52006932$

${ }^{5}$ See: $\underline{\text { https://libguides. } \text { kennesaw.edu/ld.php?content id=50088771 }}$ 


\begin{tabular}{|c|c|c|c|c|c|}
\hline Characteristics & $\begin{array}{l}\text { Black Teachers } \\
\text { Matter (BTM) }\end{array}$ & $\begin{array}{c}\text { Advanced } \\
\text { Qualitative } \\
\text { Research Methods } \\
\text { (AQRM) }\end{array}$ & $\begin{array}{l}\text { Comparative } \\
\text { Education (CE) }\end{array}$ & $\begin{array}{c}\text { Conceptual } \\
\text { Frameworks \& } \\
\text { Research Design } \\
\text { (CFRD) }\end{array}$ & $\begin{array}{c}\text { Senior Capstone } \\
\text { in Human Services } \\
\text { (SCHS) }\end{array}$ \\
\hline & $\begin{array}{l}\text { students to reach a } \\
\text { deep understanding of } \\
\text { the key elements to be } \\
\text { included in well- } \\
\text { informed research } \\
\text { designs. }\end{array}$ & $\begin{array}{l}\text { a visual } \\
\text { representation of the } \\
\text { key elements of the } \\
\text { research designs for } \\
\text { their dissertations. }\end{array}$ & $\begin{array}{l}\text { generate a } \\
\text { literature review } \\
\text { synthesis matrix. }\end{array}$ & $\begin{array}{l}\text { a visual } \\
\text { representation of the } \\
\text { components of the } \\
\text { conceptual } \\
\text { framework supporting } \\
\text { their dissertation } \\
\text { studies. }\end{array}$ & $\begin{array}{l}\text { students to } \\
\text { generate a research } \\
\text { design for their } \\
\text { senior capstone } \\
\text { projects. }\end{array}$ \\
\hline $\begin{array}{l}\text { Developed in the } \\
\text { framework of } \\
\text { practice-based } \\
\text { research approaches }\end{array}$ & $\begin{array}{l}\text { Students were asked } \\
\text { to collaboratively } \\
\text { generate their own } \\
\text { research designs to } \\
\text { tackle issues affecting } \\
\text { Black Youth and } \\
\text { institutionalized } \\
\text { racism. }\end{array}$ & $\begin{array}{l}\text { Students developed } \\
\text { the research design } \\
\text { for their own } \\
\text { dissertation. } \\
\text { Students are full-time } \\
\text { teachers usually } \\
\text { analyzing issues } \\
\text { affecting their } \\
\text { practice }\end{array}$ & $\begin{array}{l}\text { Students developed } \\
\text { a literature review } \\
\text { synthesis matrix, } \\
\text { identifying issues in } \\
\text { the field of } \\
\text { Comparative } \\
\text { Education and } \\
\text { Policy Studies }\end{array}$ & $\begin{array}{l}\text { Students developed a } \\
\text { visual representation } \\
\text { of the conceptual } \\
\text { framework to support } \\
\text { their dissertation } \\
\text { topic. Students are } \\
\text { full-time teachers } \\
\text { usually analyzing } \\
\text { issues affecting their } \\
\text { practice }\end{array}$ & $\begin{array}{l}\text { Students developed } \\
\text { a research design } \\
\text { for a study analyzing } \\
\text { a practical issue in a } \\
\text { local non-profit } \\
\text { organization or } \\
\text { public agency }\end{array}$ \\
\hline $\begin{array}{l}\text { The design purpose } \\
\text { is flexible and can } \\
\text { vary in different } \\
\text { iterations }\end{array}$ & \multicolumn{5}{|c|}{ The implementation of the session was fluid, and personalized to students previous knowledge. } \\
\hline $\begin{array}{l}\text { It requires a shared } \\
\text { experience that } \\
\text { catalyzes teamwork }\end{array}$ & $\begin{array}{l}\text { The three faculty in } \\
\text { charge of the group of } \\
\text { students, shared with } \\
\text { the IRML's team the } \\
\text { basis and aims of their } \\
\text { work, as well as the } \\
\text { readings and activities } \\
\text { already shared with } \\
\text { students. }\end{array}$ & $\begin{array}{l}\text { The co-design was } \\
\text { developed between } \\
\text { the faculty in charge } \\
\text { of the course and the } \\
\text { IRML's team. The } \\
\text { course syllabus, goals } \\
\text { and assignments } \\
\text { were analyzed to } \\
\text { plan the session. }\end{array}$ & $\begin{array}{l}\text { The co-design was } \\
\text { developed between } \\
\text { the faculty in } \\
\text { charge of the } \\
\text { course and the } \\
\text { IRML's team. The } \\
\text { course syllabus, } \\
\text { goals and } \\
\text { assignments were } \\
\text { analyzed to plan } \\
\text { the session. }\end{array}$ & $\begin{array}{l}\text { The co-design was } \\
\text { developed between } \\
\text { the faculty in charge } \\
\text { of the course and the } \\
\text { IRML's team. The } \\
\text { course syllabus, goals } \\
\text { and assignments were } \\
\text { analyzed to plan the } \\
\text { session. }\end{array}$ & $\begin{array}{l}\text { The co-design was } \\
\text { developed between } \\
\text { the faculty in charge } \\
\text { of the course and } \\
\text { the IRML's team. } \\
\text { The course syllabus, } \\
\text { goals and } \\
\text { assignments were } \\
\text { analyzed to plan the } \\
\text { session. }\end{array}$ \\
\hline $\begin{array}{l}\text { It must comply with } \\
\text { and respect the cycle } \\
\text { and the rhythms of } \\
\text { the real context of } \\
\text { application }\end{array}$ & \multicolumn{5}{|c|}{ The session in the IRML was included as a regular activity within the weekly meetings of the group. } \\
\hline $\begin{array}{l}\text { It requires strong } \\
\text { facilitation by the } \\
\text { drivers of the } \\
\text { process and well- } \\
\text { defined roles for all } \\
\text { participants. }\end{array}$ & $\begin{array}{l}\text { A member of the IRML } \\
\text { was in charge of } \\
\text { driving the co-design } \\
\text { process in } \\
\text { collaboration with } \\
\text { three faculty already } \\
\text { working with the } \\
\text { group of students. }\end{array}$ & $\begin{array}{l}\text { A member of the } \\
\text { IRML was in charge } \\
\text { of driving the co- } \\
\text { design process in } \\
\text { collaboration with } \\
\text { the faculty teaching } \\
\text { the course. }\end{array}$ & $\begin{array}{l}\text { Two members of } \\
\text { the IRML were in } \\
\text { charge of driving } \\
\text { the co-design } \\
\text { process in } \\
\text { collaboration with } \\
\text { the faculty teaching } \\
\text { the course. }\end{array}$ & $\begin{array}{l}\text { A member of the } \\
\text { IRML was in charge of } \\
\text { driving the co-design } \\
\text { process in } \\
\text { collaboration with the } \\
\text { faculty teaching the } \\
\text { course. }\end{array}$ & $\begin{array}{l}\text { A member of the } \\
\text { IRML was in charge } \\
\text { of driving the co- } \\
\text { design process in } \\
\text { collaboration with } \\
\text { the faculty teaching } \\
\text { the course. }\end{array}$ \\
\hline $\begin{array}{l}\text { Clear distribution of } \\
\text { responsibilities for } \\
\text { the quality of the co- } \\
\text { designed products }\end{array}$ & $\begin{array}{l}\text { The session was } \\
\text { facilitated by } 3 \text { faculty } \\
\text { and one member of } \\
\text { the IRML }\end{array}$ & $\begin{array}{l}\text { The session was } \\
\text { facilitated by } 1 \\
\text { faculty and one } \\
\text { member of the IRML }\end{array}$ & $\begin{array}{l}\text { The session was } \\
\text { facilitated by one } \\
\text { faculty and two } \\
\text { members of the } \\
\text { IRML }\end{array}$ & $\begin{array}{l}\text { The session was } \\
\text { facilitated by } 1 \text { faculty } \\
\text { and one member of } \\
\text { the IRML }\end{array}$ & $\begin{array}{l}\text { The session was } \\
\text { facilitated by } 1 \\
\text { faculty and one } \\
\text { member of the IRML }\end{array}$ \\
\hline Delivery Format & \multicolumn{5}{|c|}{ Face-to-Face \& virtual interaction } \\
\hline Data Collection & \multicolumn{5}{|c|}{ Case study evaluative process } \\
\hline
\end{tabular}


Co-design sessions followed the four phases identified by Barberá et al. (2017) and Cober et al. (2015):

a. Exploration phase: Faculty teaching the courses for which the lessons were designed contacted the IRML team. An initial meeting was held to discuss the pedagogical challenge(s) they were facing as well as their motivation and goals for integrating the IRML into their lessons. In this initial meeting, the IRML team also demonstrated how the lab functions and described its affordances for teaching and learning.

b. Envisioning phase: A workshop session involving faculty and IRML team members was held to determine the specific objectives of the proposed lesson, the tangible product(s) students would be required to generate, and the co-design process to be followed.

c. Operationalization phase: In an iterative fashion, faculty and IRML team members codeveloped a lesson plan that would be implemented with students soon thereafter. The lesson plan included learning goals, a teaching script, a set of resources, and the collaborative learning strategies to be implemented during the class.

d. Assessment and reflection phase: After implementing the lesson plan, faculty and students who participated in the lesson completed a reflective questionnaire evaluating their experience. The quality of the products they generated was also evaluated.

To illustrate our processes more thoroughly, in the following sections we provide in-depth descriptions of the entire co-design process for two of the five lesson on which our work is based.

\subsection{Co-designing a lesson plan for an undergraduate senior capstone.}

The Senior Capstone in Human Services (SCHS) is the final course taken by students pursuing a Bachelor of Science in Human Services (BHS) degree at Kennesaw State University. The degree is designed to provide an educational foundation for those who wish to build a rewarding career helping those who are experiencing social and personal problems. The multidisciplinary nature of the degree program prepares students to become competent as human services professionals for multiple roles and settings. The BHS degree program is an application-oriented major, based on a synthesis of knowledge and skills to intervene at the individual, group, and community levels.

SCHS students are required to conduct a semester-long internship with a local client (i.e., nonprofit organization, school, community group, or public institution). The 15-week course demands that students collaboratively identify an issue their clients are facing, conduct research on the issue, and propose potential solutions. The course meets weekly for a 3-hour face-to-face session in which the instructor guides students through designing, implementing, and reporting on their research projects. 
The class met in the IRML during week four (see Figure 3 for a summary of content covered in each weekly meeting). Prior to teaching a lesson in the lab, however, the course instructor and the IRML team worked through the co-design process to develop a lesson plan:

a. Exploration phase: Two members of the IRML team met with the course instructor to review the SCHS syllabus, putting special emphasis on the description and goals of the research project students must design and implement within the organization hosting their internships. Next, members of the IRML team showed the course instructor how the IRML operates, and presented various lesson plans that had been co-designed and implemented previously in the lab.

\begin{tabular}{|l|l|}
\hline Week & Content \\
\hline Week 1 & Welcome and Introduction to Senior Capstone \\
\hline Week 2 & $\begin{array}{l}\text { 1st Coaching Appointment: Brainstorm/discussion session to identify possible areas of research } \\
\text { and potential deliverables within the organization in echo the student is conducting the internship. }\end{array}$ \\
\hline Week 3 & Conducting a literature review \\
\hline Week 4 & $\begin{array}{l}\text { Development of study Prospectus and Research Design (Session in the Interactive Research } \\
\text { Methods Lab) }\end{array}$ \\
\hline Week 5 & $\begin{array}{l}\text { Workshop session to finalize the literature review and the prospectus off the study, and the } \\
\text { research design initiated in the Interactive Research Methods Lab }\end{array}$ \\
\hline Week 6 & Workshop session to finalize the research design initiated in the Interactive Research Methods Lab \\
\hline Week 7 & Session with Library and Writing Center Staff for additional support \\
\hline Week 8 & Workshop session to begin crafting the course deliverable \\
\hline Week 9 & Feedback Session on Completed Literature Reviews \\
\hline Week 10 & Workshop session to keep on working in the course deliverable \\
\hline Week 11 & Workshop session to finalize the Mock Up Binders for the course \\
\hline Week 12 & Workshop session to finalize the Mock Up Binders for the course \\
\hline Week 13 & Workshop session to prepare for Symposium for Student Scholars' Presentations \\
\hline Week 14 & 1:1 Coaching prior to final binder and presentations, as scheduled \\
\hline Week 15 & Symposium for Student Scholars' Presentations \\
\hline
\end{tabular}

Figure 3. Course Content by Week in Senior Capstone in Human Services (SCHS)

b. Envisioning phase: One week later, a two-hour workshop was organized in which the instructor and IRML team members defined goals, developed learning activities, and discussed the tangible product students would have to generate during the session that would be held in the IRML. To facilitate the process, the group created a shared template based on the structure that typically was used in the IRML to develop lesson plans. Figure 4 details the decisions made during the session. 


\begin{tabular}{|c|c|}
\hline $\begin{array}{l}\text { Definition of the } \\
\text { goals for the } \\
\text { session }\end{array}$ & $\begin{array}{l}\text { a) Help students develop their research skills; b) Help students develop their communication } \\
\text { and critical thinking skills, and; c) guide students in developing a methodologically-sound } \\
\text { research design for their senior capstone projects. }\end{array}$ \\
\hline $\begin{array}{l}\text { Elaboration of a } \\
\text { tentative teaching } \\
\text { script: Teaching } \\
\text { Activities }\end{array}$ & $\begin{array}{l}\text {-Step 0: Prior to the face-to-face session in the IRML, the instructor of the course will } \\
\text { describe the activity and the Lab to students taking HS } 4900 \text {. } \\
\text {-Step 1: The instructor in collaboration with a member of the IRML team, will present the } \\
\text { activity to be conducted in the IRML, and its relationship with the previous activities } \\
\text { conducted in the course. }\left(10^{\prime}\right) \\
\text {-Step 2: An IRML team member will briefly introduce the origin and functioning of the } \\
\text { Interactive Research Methods Lab and the Hopscotch Model. }\left(10^{\prime}\right) \\
\text {-Step 3: Hands-on session. In pairs, students will interact with the augmented reality } \\
\text { contents included in each of the nine steps conforming the Lab. In this stage, students will } \\
\text { have to individually fill out a template including the key elements that need to be } \\
\text { considered to generate a solid research design for their own study. }\left(50^{\prime}\right) \\
\text {-Step 4: Each student will present in front of the class }\left(5^{\prime}\right) \text { the resultant of the previous step } \\
\text { with the aim of discussing it. }\left(35^{\prime}\right)\end{array}$ \\
\hline $\begin{array}{l}\text { Description of the } \\
\text { tangible product } \\
\text { to be generated } \\
\text { by students }\end{array}$ & $\begin{array}{l}\text { Students will have to individually present a template with the nine key elements defining } \\
\text { their research study. (see appendix A in: https://tinyurl.com/y2tsmvs4) }\end{array}$ \\
\hline Resources & $\begin{array}{l}\text {-Examples of Undergraduate Research Projects } \\
\text {-IRML Guide/Website } \\
\text {-Hopscotch Model } \\
\text {-A template like the one students will have to produce, filled out with an example from the } \\
\text { research design generated by a former student (see appendix B in: } \\
\text { https://tinyurl.com/y2tsmvs4) }\end{array}$ \\
\hline
\end{tabular}

Figure 4. Summary of Outcomes from the SCHS Envisioning Phase

c. Operationalization phase: We conducted this phase of the process on-line using OneDrive (Office 365). Over the course of one week, the co-design group collaborated to refine and finalized the lesson plan (which can be viewed at https://tinyurl.com/y2tsmvs4). Particular attention was given to developing the resources that would help students navigate the session, which was successfully implemented with the SCHS students on January 31st, 2020, from 10:30 am to 12:30 pm (see figure 5).

d. Assessment and Reflection phase: The SCHS session was included in the overall evaluation plan developed by the IRML team to assess the quality of the support provided by the IRML to both instructors and students. At the end of the session in the IRML, the course instructor and the five participating students voluntarily completed a reflective questionnaire to assess the co-design process (faculty), and the quality of implementation of the session (students). The learning products (i.e., research designs) generated in the session were also collected and included in the evaluation. 


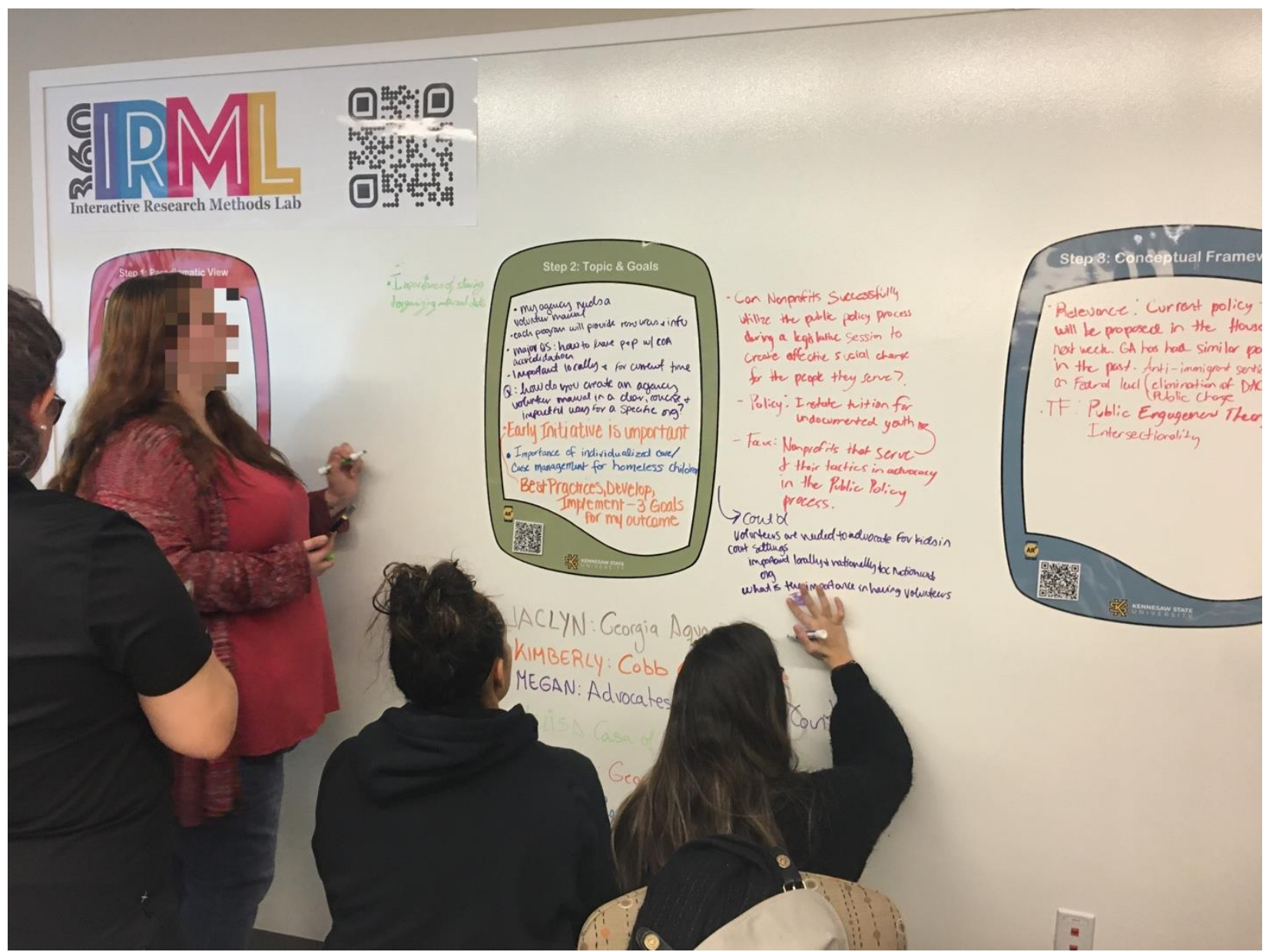

Figure 5. HS 4900-Senior Capstone Students in the IRML

\subsection{Co-designing a Lesson Plan for a Graduate Course on Conceptual Frameworks \& Research Design.}

Conceptual Frameworks and Research Design (CFRD) is the final seminar doctoral students take in the Doctorate of Education programs offered by the Bagwell College of Education (Kennesaw State University). This 3-credit seminar assists doctoral candidates in conceptualizing, identifying the components of, and articulating the emerging conceptual framework of their dissertations. Moreover, the course helps students connect and align the developed conceptual framework with the specific research design to be used in their dissertation studies. The final learning product generated in the course, a conceptual framework, is instrumental for students' comprehensive exams and dissertation proposals because it offers a summary of the initial three chapters of their dissertations. Although the course is fully on-line, a 2-hour face-to-face session is held in the IRML to assist students in creating a visual representation of the key elements 
comprising the conceptual framework. Figure 6 summarizes the content for each week in the 15week course.

\begin{tabular}{|l|l|}
\hline Week & Content \\
\hline Week 1 & Introduction to the course \\
\hline Weeks 2 \& 3 & Conceptual Frameworks explored and defined. What and where is theory? \\
\hline Weeks 4 \& 5 & $\begin{array}{l}\text { Paradigms in Educational Research: Positivism, post-positivism, interpretivism, and critical } \\
\text { paradigm. }\end{array}$ \\
\hline Weeks 6 \& 7 & $\begin{array}{l}\text { Role of Conceptual Frameworks in Quantitative Designs/Qualitative Designs/Mixed Methods } \\
\text { Designs }\end{array}$ \\
\hline Weeks 8 \& 9 & The role of Conceptual Frameworks in Excavating Research Questions \\
\hline Week 10 & The role of Conceptual Frameworks in Data Collection. Face-to-face session in the IRML \\
\hline Week 11 & The role of Conceptual Frameworks in Data Analysis \\
\hline Week 12 & Role of Conceptual Frameworks in Explaining and Contextualizing Findings \\
\hline Week 13 & Conceptual Frameworks as guide and ballast \\
\hline Weeks 14 \& 15 & Final presentation \& Submission of final conceptual framework \\
\hline
\end{tabular}

Figure 6. Course Contents by Week in Conceptual Frameworks and Research Design

The co-design process employed by the course instructor and the IRML team followed the same four-phase progression used with the SCHS instructor:

a. Exploration phase: The instructor of the course and a member of the IRML team held an initial meeting in which the instructor shared the course syllabus, highlighting the description of the final evolving version of the conceptual framework (Ravitch \& Riggan, 2017) that students were asked to develop.

b. Envisioning phase: Three days after the initial meeting, a two-hour workshop was held, in which the instructor and IRML team member collaborated to define the goals for the class session to be held in the IRML, develop teaching/learning script for the learning activities, and discuss the tangible product students would generate. To facilitate the process, the grouped created a shared template based on the structure that typically was used in the IRML to develop lesson plans. Figure 7 details the decisions that were reached in this phase of the process.

c. Operationalization phase: Again, this phase was conducted on-line. The co-design group collaborated over a three-week period to refine the lesson plan and develop the final version, which can be viewed at https://tinyurl.com/y3qvyera. A strong emphasis was placed upon the development of a tool (based on Google Forms and Google Apps Scripts) that would help students automatically develop visual representations of their conceptual frameworks (the tool can be accessed at https://hopscotchmodel.com/conceptual-framework/). The Google Form, which asked a series of questions related to each component of the students' conceptual frameworks. The Google Form also included multimedia contents to assist students in making informed decisions about each question. After submitting their forms, a 
PDF file with a visual representation of their generated conceptual framework was sent to each student (see figure 8). The email also included a link so the student could refine the visual representation as needed. The session was successfully implemented on October 10th, 2019 from 17:30 to 19:30 pm (see figure 9).

\begin{tabular}{|l|l|}
\hline $\begin{array}{l}\text { Definition of the } \\
\text { goals for the } \\
\text { session }\end{array}$ & $\begin{array}{l}\text { a) Help students settle their research skills; b) Help students develop their communication } \\
\text { and critical thinking skills, and; c) guide students in developing a visual representation of the } \\
\text { key elements conforming the conceptual frameworks for their dissertations. }\end{array}$ \\
\hline $\begin{array}{l}\text { Elaboration of a } \\
\text { tentative teaching } \\
\text { script }\end{array}$ & $\begin{array}{l}\text {-Step 0: Prior to the face-to-face session in the IRML, students will receive this didactic unit } \\
\text { so they can be aware of the activity to be conducted. } \\
\text {-Step 1: The IRML will be presented to the students (15') } \\
\text {-Step 2: Construct a visual display or representation of the concepts and the relationships } \\
\text { between the concepts of your evolving conceptual framework (45'). The visual display } \\
\text { should clearly include the three components proposed by Ravitch \& Riggan (2017): a) } \\
\text { Identity and positionality; b) personal connection with the topic and goals; c) Literature } \\
\text { review including topical research, and theoretical frameworks. In addition the visual should } \\
\text { also include: a) the gap/s found in the literature; b) the problem statement; d) research } \\
\text { questions, and the e) research design that will be implemented. } \\
\text {-Step 3: Students will present/share with the rest of the group the visual representation of } \\
\text { their studies (60') (7+7 minutes each) }\end{array}$ \\
\hline $\begin{array}{l}\text { Description of the } \\
\text { tangible product } \\
\text { to be generated } \\
\text { by students }\end{array}$ & $\begin{array}{l}\text { Students will have to individually create and present in front of the group a visual } \\
\text { representation of the conceptual frameworks for their dissertations. }\end{array}$ \\
\hline Resources & $\begin{array}{l}\text {-Examples of visual representations of conceptual frameworks: (http://tiny.cc/7c0aez) } \\
\text {-IRML Guide/Website } \\
\text {-Hopscotch Model } \\
- \text {-Tool to assist the generation of the visual representation of the conceptual framework: } \\
\text { https://hopscotchmodel.com/conceptual-framework/ }\end{array}$ \\
\hline
\end{tabular}

Figure 7. Summary of Outcomes from the CFRD Envisioning Phase

d. Assessment and reflection phase: This session was also included in the overall evaluation plan developed by the IRML team to assess the quality of the support provided by the IRML team members to both instructors and students. The course instructor and the six participating students voluntarily completed a reflective questionnaire to evaluate the session. Student artifacts (i.e., visual representations of the conceptual frameworks) generated during the session were also analyzed in order to evaluate learning outcomes. 
Email:

Date: $10 / 21 / 201918 \cdot 42 \cdot 24$

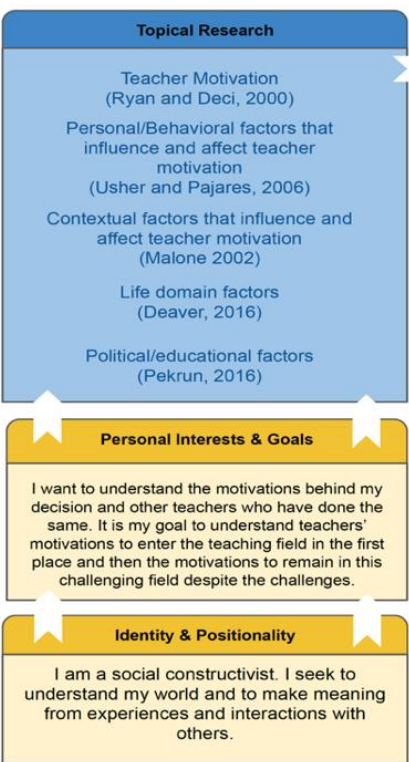

Research Topic: Teacher Motivations to Enter and Remain in the Profession

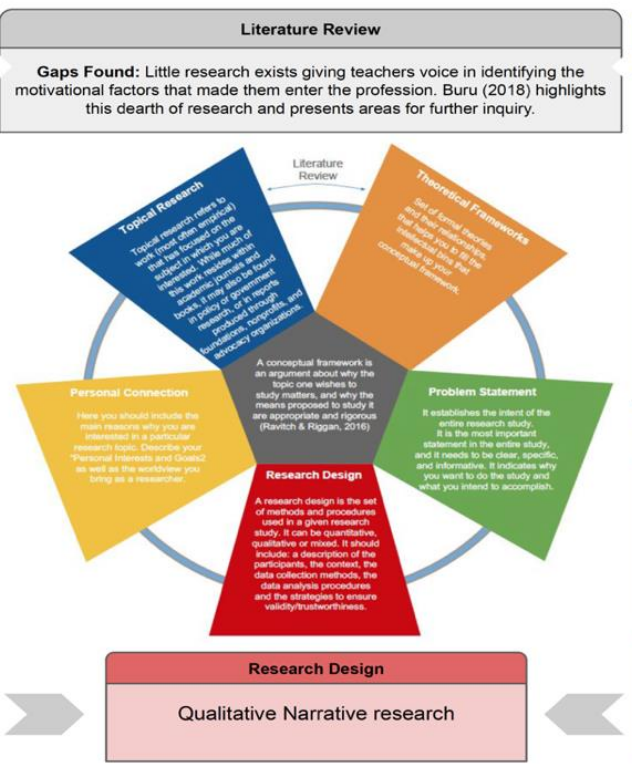

\section{Hopscotch sogeso}

\begin{tabular}{|l|}
\hline Theoretical Frameworks \\
Self-Efficacy Theory \\
(Pajares, 1996) \\
Achievement Goal Theory \\
(Schunk, 1990) \\
Self Determination Theory \\
(Ryan \& Deci, (2000) \\
Control Value Theory \\
(Pekrun, 2006) \\
Expectancy Value Theory \\
(Wigfield \& Eccles 2000)
\end{tabular}

Figure 8 . Visual representation generated by a student using the co-developed tool

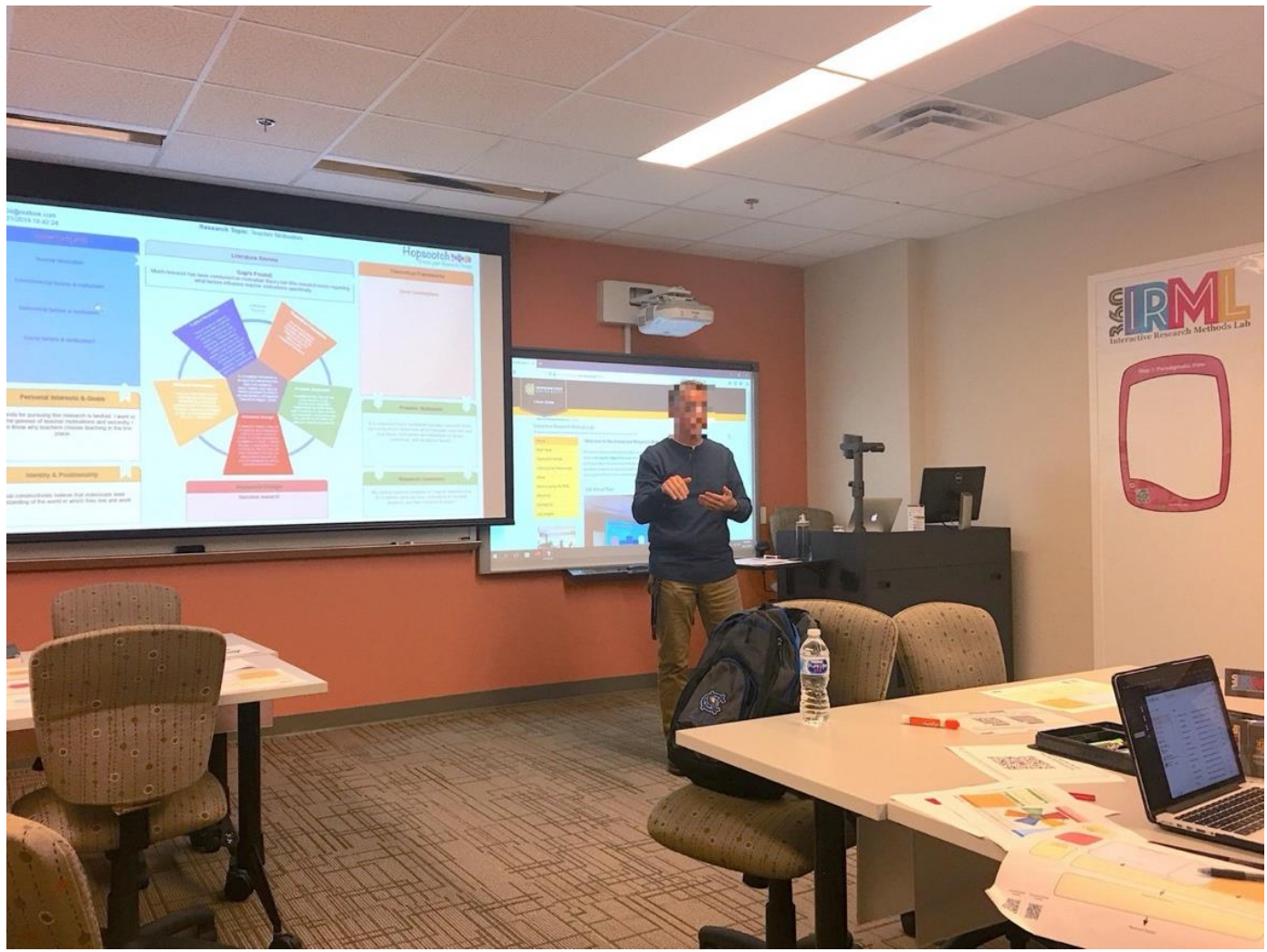

Figure 9. Graduate student presenting the visual representation of his conceptual framework 


\section{ONGOING STUDY.}

In an effort to assess the impact of the sessions conducted in the IRML on the teaching and learning of research methods, and to identify opportunities to enhance the IRML's utility and effectiveness, we have devised three research questions: a) Is the IRML helping faculty teach research methods in innovative and meaningful ways? b) Is the IRML helping students understand the complexities involved in generating quantitative, qualitative, and mixed-methods research designs in education? c) Which aspects of the IRML do we need to enhance in order to better support the teaching and learning of research design in education?

An evaluative case study (Stake, 1995) is being conducted to answer these questions. Figure 10 illustrates the key components of the case study (IRB Study \#20-139), including descriptions of the informants, data collection methods, additional document analysis, case study strategies employed, and tools used in data collection and analysis.

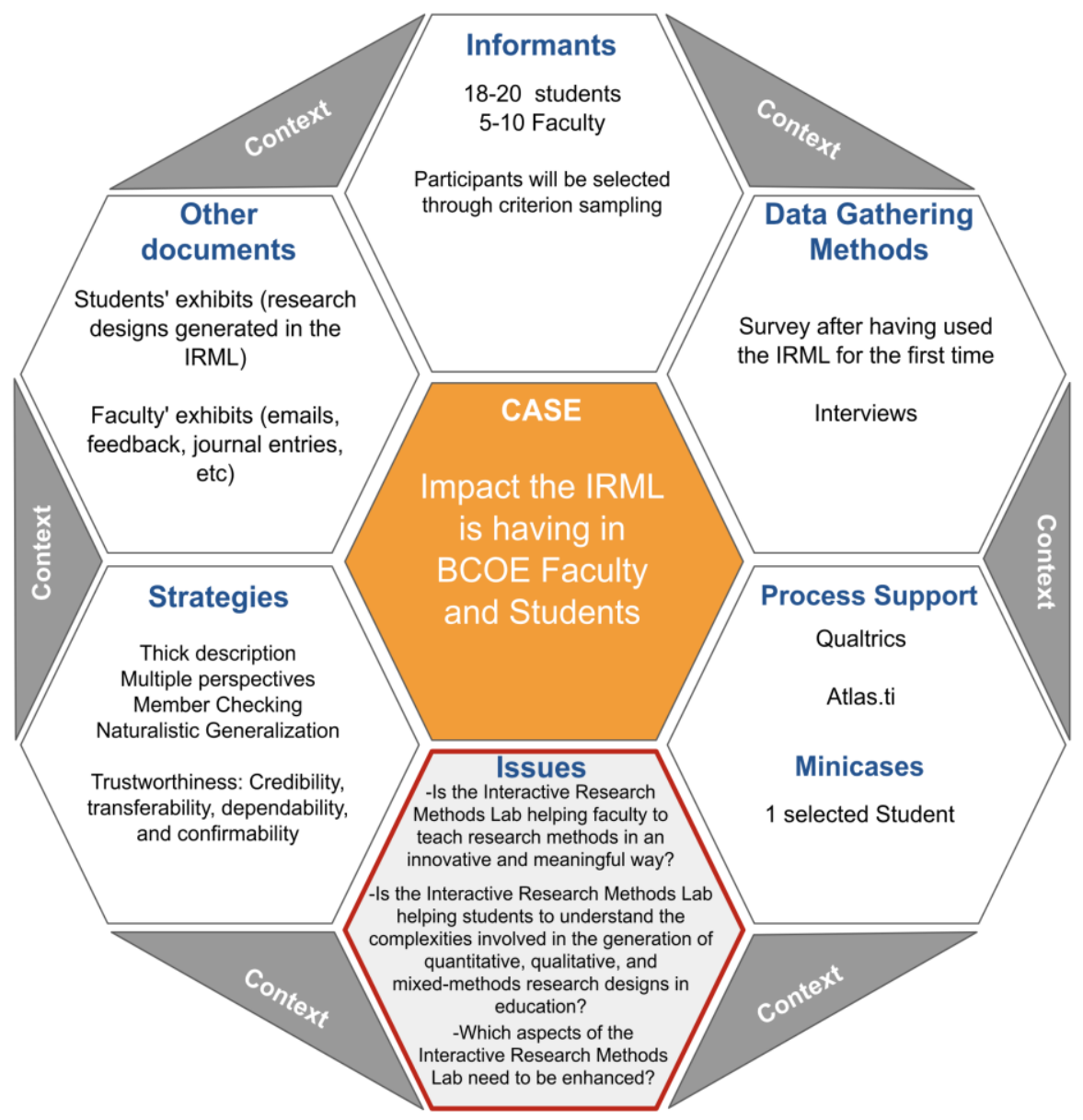

Figure 10. Visual Representation of the Evaluative Case Study Design of the IRML 


\section{TENTATIVE RESULTS.}

At the time of this paper's submission (July 2020), we are still in the process of collecting and analyzing data. In this section, we present tentative results emerging from the analysis of the survey responses of seven faculty and seventeen students who voluntarily participated in the study. More conclusive findings are expected to be ready for publication by the end of fall 2020 . These findings will be based on the triangulation of three main data sources: user surveys (see figure 11), interviews with participants, and session artifacts (i.e., students' learning products and faculty lesson plans).

Preliminary analysis of the online survey responses from students and faculty who participated in the five sessions described in table 1 reveal promising results. An overall network view generated using Atlas.ti (see Figure 12) summarizes the density of the analysis, the number of participants, and their responses to the six survey questions.

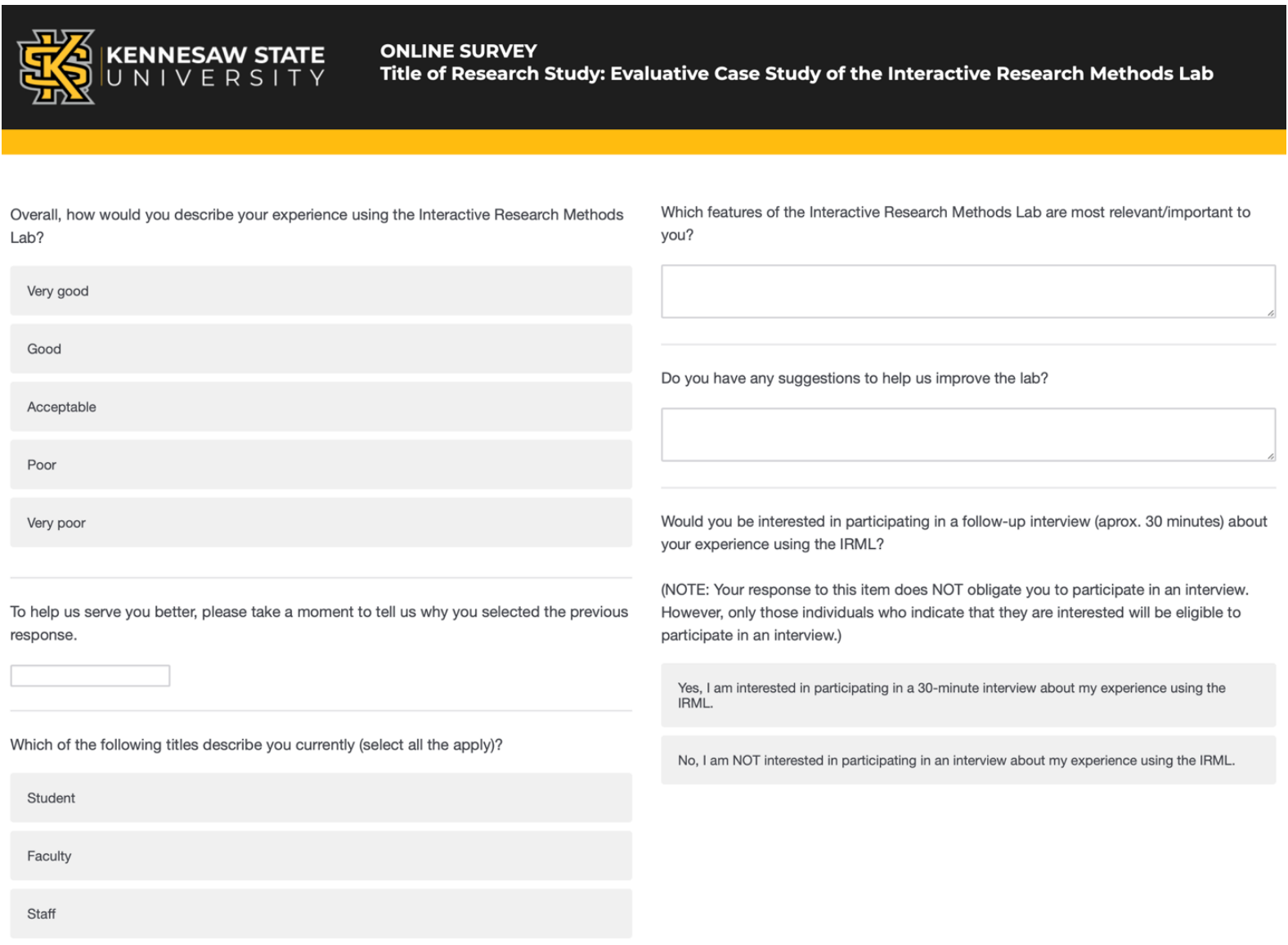

Figure 11. Qualtrics Survey 
Seventeen of the twenty-four participants (7 faculty, 10 students) who voluntarily responded to the survey described their experience in the lab as "very good." Six students described it as "good" and one as "acceptable." Previous results underscore that $95.8 \%$ of the participants valued the teaching and learning experiences in the IRML as "positive" or "very positive." For example, one of the undergraduate students who participated in the SCHS session commented, "I loved all aspects of the lab. I appreciate the videos that accompanied each station providing a detailed explanation of each stage in a research process."

A student participating in the CE session asserted that "[...] the session in the lab was invaluable in directing us towards an understanding of the literature review [...]" One student who participated in the SCHS session also highlighted that "the lab was filled with helpful resources" and that the overall experience was "well designed and informative." This student also expressed that the information provided within each of the steps involved in generating their research designs was "incredibly detailed." It is also noteworthy that the CFRD students, who participated in the face-to-face IRML session despite being enrolled in fully online courses, valued the virtual components of the lab and the across-spaces design, which afforded them remote access to the IRML and all its resource. For example, in response to a question about the most relevant/important features of the IRML, one CFRD student highlighted the "[...] anytime, anywhere access" offered by the virtual component of the lab and the "[...] great resources and step by step guides and builder tools" that are provided.

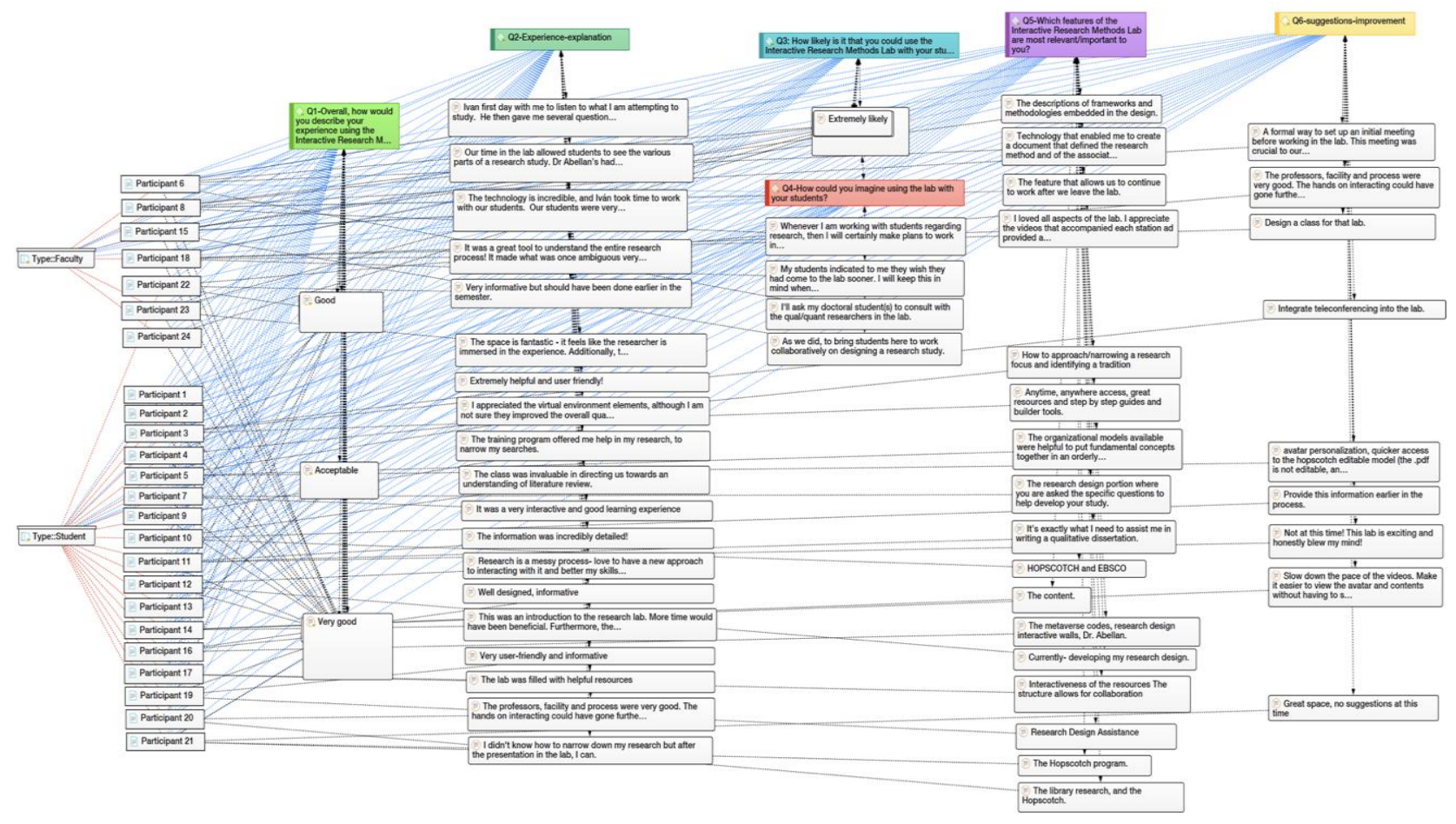

Figure 12. Atlas.ti Network View of Responses Provided by Students and Faculty 
Overall, faculty evaluations of the sessions conducted in the lab were also positive. All six faculty who completed the survey described their overall experience with the IRML as "very good." In addition, all surveyed faculty responded that it is "extremely likely" that they will use the lab with their students again in the near future. One faculty member noted, "[...] the space is fantastic - it feels like you are immersed in the experience [...]" A second instructor highlighted that the IRML is a "[...] great tool to understand the entire research process! It made what was once ambiguous very clear [...]" In the same regard, another instructor mentioned that she "loved the lab," particularly "the videos that accompanied each station." The instructor who participated in the co-design sessions for the CSHS course stated that " [...] the [co-design] sessions to plan the activity in the lab were extremely helpful.

The current analysis has also illuminated areas for improvement. Specifically, there were three prevalent themes in participants' suggestions about how the learning/teaching experiences in the IRML could be enhanced: a) integration of a video-conferencing system to better assist online students; b) decreased pace for some of the multimedia accompanying each step of the process, and; c) student-enabled personalization of the gender and ethnicity of the virtual avatar that guides users through the AR contents.

The current findings, although tentative, already show promising trends. In the coming months, interviews with student and faculty participants, as well as in-depth analysis of the learning products generated by students will provide a more thorough understanding of the co-design process and the implementation of co-designed lesson plans.

\section{CONCLUSIONS \& FUTURE WORK}

In this paper we have presented five co-design sessions aimed at developing research methods lesson plans for undergraduate and graduate students that were implemented in the Interactive Research Methods Lab.

While the study is ongoing, preliminary findings indicate that using a co-design approach for the development and implementation of authentic and meaningful learning experiences might be a practical solution to the inherently daunting nature of the teaching and learning of research methods (Cooper et al., 2012; Lesko et al., 2008).

Seminal studies in the field of teaching and learning research methods (Breuer \& Schreier, 2007; Günter, 2008; Hammersley, 2004) underscore the need for new models, tools, and guiding frameworks to ameliorate some of the challenges and nuances in teaching research methods instruction (Hazzan \& Nutov, 2014). We believe that the proposal presented in this article, based on the collaborative implementation of lesson plans co-designed by instructors and researchers using the IRML as a methodological and technological learning artifact, could be an initial step in 
a promising direction for facilitating improved teaching and learning in research methods courses.

Our co-design proposal also tackles one of the main findings posed by Freeman et al. (2014), who concluded that the main challenge faced by faculty teaching research methods and statistics is making course content relevant and engaging for students while simultaneously improving students' understanding of research methods. Our findings evidence that the co-designed lesson plans implemented in the IRML offer an alternative approach for teaching research methods; one that is active, meaningful, and deeply connected to students' contexts and needs.

Our research team is currently analyzing the remaining data (i.e. surveys, interviews, artifacts) from the five sessions described in this article. Simultaneously, new co-design sessions are being held in the IRML. Data from both previous and new co-design sessions will be integrated by the end of 2020, when more conclusive findings are expected to be released.

\section{REFERENCES}

Barberá, E., Garcia, I., \& Fuertes-Alpiste, M. (2017). A Co-Design Process Microanalysis: Stages and Facilitators of an Inquiry-Based and Technology-Enhanced Learning Scenario. International Review of Research in Open \& Distance Learning, 18(6), 104-126. https://doi.org/10.19173/irrodl.v18i6.2805

Breuer, F., Schreier, M. (2007). Issues in learning about and teaching qualitative research methods and methodology in the social sciences. Forum: Qualitative Social Research, 8(1), 1-17, http://dx.doi.org/10.17169/fqs-8.1.216

Cober, R., Tan, E., Slotta, J., So, H-S., \& Könings, K. D. (2015). Teachers as participatory designers: two case studies with technology-enhanced learning environments. Instructional Science, 43(2), 203-228. 10.1007/s11251-014-9339-0

Cooper, R., Fleischer, A., \& Cotton, F. A. (2012). Building Connections: An Interpretative Phenomenological Analysis of Qualitative Research Students' Learning Experiences. Qualitative Report, 17(1), 1-16. https://nsuworks.nova.edu/tqr/vol17/iss17/1

Dewey, J. (1916). Democracy and education: An introduction to the philosophy of education. Macmillan.

European Commission (2016). Open innovation, open Science, open to the world: A vision for Europe. Brussels: European Commission, Directorate-General for Research and Innovation. doi:10.2777/061652

Freeman, S., Eddy, S. L., McDonough, M., Smith, M. K., Okoroafor, N., Jordt, H., \& Wenderoth, M. P. (2014). Active learning increases student performance in science, engineering, and 
mathematics. Proceedings of the National Academy of Sciences of the United States, 23, 84108415. https://doi.org/10.1073/pnas.1319030111

García, I, Barberá, E., Gros, B., Escofet, A., Fuertes, M. Noguera, I., López, M., Cortada, M., \& Marimón, M. (2014). Analysing and supporting the process of co-designing inquiry-based and technology-enhanced learning scenarios in higher education. In Bayne, S., Jones, C., de Laat, M., Ryberg, T., \& Sinclair, C. (Eds.), Proceedings of the Ninth International Conference on Networked Learning (493-501).

Gullo, D. F. (2013). Improving instructional practices, policies, and student outcomes for early childhood language and literacy through data-driven decision-making. Early Childhood Education Journal, 41(6), 413-421. https://doi.org/10.1007/s10643-013-0581-x

Günter, M. (2008). A lesson learned? Difficulties in teaching and learning qualitative research methods. Journal Für Psychologie, 1 (5). 1-13. https://www.journal-fuerpsychologie.de/index.php/jfp/article/view/194

Hammersley, M. (2004). Teaching qualitative method: Craft, profession, or bricolage? In Clive Seale, Giampietro Gobo \& David Silverman (Eds.). Qualitative research practice (pp.549-560). Sage.

Hazzan, O., \& Nutov, L. (2014). Teaching and Learning Qualitative Research $\approx$ Conducting Qualitative Research. Qualitative Report, 19 (24), 1-29. https://nsuworks.nova.edu/tqr/vol19/iss24/3

Jorrín-Abellán, I. M. (2016). Hopscotch Building: A Model for the Generation of Qualitative Research Designs. Georgia Educational Researcher, 13 (1). 10.20429/ger.2016.130104.

Jorrín-Abellán, I. M. (2019) Hopscotch 2.0: an enhanced version of the Model for the Generation of Research Designs in Social Sciences and Education. Georgia Educational Researcher, 16 (1) 10.20429/ger.2019.160103

Lesko, N., Simmons, J.A., Quarshie, A., \& Newton, N. (2008). The Pedagogy of Monsters: Scary Disturbances in a Doctoral Research Preparation Course. Teachers College Record, 110 (8), 1541-1573. http://www.tcrecord.org/Content.asp?Contentld=15152

Könings, K. D., Brand-Gruwel, S. \& Van Merriënboer, J. J. G. (2011). Participatory instructional redesign by students and teachers in secondary education: effects on perceptions of instruction. Instructional Science, 39(5), 737-762. https://doi.org/10.1007/s11251-010-9152$\underline{3}$

Mandinach, E. B. (2012). A Perfect Time for Data Use: Using Data-Driven Decision Making to Inform $\begin{array}{llll}\text { Practice. } & \text { Educational 71-85. }\end{array}$ https://doi.org/10.1080/00461520.2012.667064 
Marsh, J. A. (2012). Interventions promoting educators' use of data: Research insights and gaps. Teachers College Record, 114 (11), 1-48. https://eric.ed.gov/?id=EJ1001992

Muñoz-Cristóbal, J. A., Prieto, L. P., Asensio-Pérez, J. I., Martínez-Monés, A., Jorrín-Abellán, I. M., \& Dimitriadis, Y. (2015). Coming Down to Earth: Helping Teachers Use 3D Virtual Worlds in Across-Spaces Learning Situations. Educational Technology \& Society, 18 (1), 13-26. http://www.jstor.org/stable/jeductechsoci.18.1.13

Mulholland, R., McKinlay, A., \& Sproule, J. (2017). Teachers in need of space: The content and changing context of work. Educational Review, 69 (2), 181-200. 10.1080/00131911.2016.1184131

Piety, P. J. (2019). Components, Infrastructures, and Capacity: The Quest for the Impact of Actionable Data Use on P-20 Educator Practice. Review of Research in Education, 43 (1), 394-421. https://doi.org/10.3102/0091732×18821116

Ravitch S. M. \& Riggan, M. (2017) Reason and Rigor: How Conceptual Frameworks Guide Research. SAGE Publications.

Roschelle, J., Penuel, W. R., \& Shechtman, N. (2006). Co-design of innovations with teachers: Definition and dynamics. Proceedings of the International Conference of the Learning Sciences, International Society of the Learning Sciences. (pp. 606-612).

Sanders, E. \& Stappers, P. J. (2008). Co-creation and the new landscapes of design. Co-Design, 4 (1), 5-18. https://doi.org/10.1080/15710880701875068

Scheeler, M. C., Budin, S., \& Markelz, A. (2016). The role of teacher preparation in promoting evidence-based practice in schools. Learning Disabilities: A Contemporary Journal, 14 (2), 171187.

Stake, R. (1995). The art of Case Study Research. Sage Publications.

Vygotsky, L. S. (1978). Interaction between learning and development. Readings on the development of children, 23 (3), 34-41.

\section{How to cite:}

Jorrín Abellán, I. M., Vasquez, A., \& Gaines, R. (2020). Co-diseñando Unidades Didácticas sobre Métodos de Investigación en el Interactive Research Methods Lab. Edutec. Revista Electrónica De Tecnología Educativa, (74), 51-71. https://doi.org/10.21556/edutec.2020.74.1797 